\title{
The Impact of Competition on Productivity. Theory and Evidence
}

Iuliana-Tania ZLATCU ${ }^{1}$

Roxana CLODNITCHI ${ }^{2}$

\begin{abstract}
This paper reviews the theoretical and empirical literature on the impact of competition on firms' efficiency and productivity. Looking at the effects of changes in competition overtime or analysing the relationship between competition and productivity across many product markets, a large body of empirical studies finds evidence of a positive relationship between competition and productivity, greater competition on the market leading to higher levels of productivity. On the other hand, the relationship between competition and innovation is highly debated, evidence suggesting a non-linear relationship with both very high and very low degree of competition discouraging firms from innovating.
\end{abstract}

Keywords: competition, regulatory reforms, productivity, firm efficiency.

JEL classification: L40, L11, F43, D24.

DOI : 10.24818/RMCI.2018.4.410

\section{Introduction}

The impact of competition on the economy has been a subject of much interest in the economic literature. In his famous book, Wealth of Nations Book, Adam Smith (1776) stated that "monopoly... is a great enemy to good management” and, over time, economists seemed to agree with him. It is a general belief that firms in competitive markets are more stimulated to improve their efficiency, reduce costs and innovate than monopoly firms. In other words, stronger competition leads to the creation of new products, brings quality improvement, increases innovative activity. In contrast, monopoly firms have smaller incentive to innovate and to adopt better technologies or to develop new products since, as protected from competition, they already earn monopoly profits.

There is an extensive economic literature that provides empirical support to the idea that competition is beneficial for the economy, leading to an increased productivity and contributing in the end to the country's economic performance. Economic studies show that competition enhance productivity through three

\footnotetext{
${ }^{1}$ Iuliana-Tania Zlatcu, Bucharest University of Economic Studies, Romania,

Email: iuliana.zlatcu@gmail.com

${ }^{2}$ Roxana Clodnitchi, Bucharest University of Economic Studies, Romania,

Email: roxana.clodnitchi@fabiz.ase.ro
} 
different channels: (i) a reduction in mark-ups and a better reallocation of scarce resources (allocative efficiency); (ii) an improvement in the utilisation of the production factors by firms (productive efficiency) and (iii) an incentive for firms to innovate to move to the modern technology frontier (dynamic efficiency) (European Commission, 2004).

In contrast, a number of papers debates the effects of competition on productivity through the effect of competition on innovation, suggesting a non-linear relationship between competition and innovation, with both very high and very low levels of market competition giving rise to lower incentives to innovate and reducing thus dynamic efficiency.

This paper presents evidence from theoretical and empirical studies on the link between competition and productivity and describes the main mechanisms through which competition can be expected to affect firms' efficiency and ultimately productivity growth.

\section{Recent Trends in European Union Markets}

Before exploring the relationship between competition and productivity growth, we focus on the recent reforms in the European Union aimed to enhance competition among suppliers of goods and services and why competition matters.

The last decades have witnessed a clear direction of the European countries oriented towards market liberalisation and deregulation, as a way to enhance economic activity and growth. Several European countries have undertaken important regulatory reform in order to liberalise essential economic sectors, as energy, transport, communications, retail trade and professional services. Such reforms aimed to remove barriers to entry and to open markets up to competition and involved several measures: (i) measures to open up markets that were formerly protected from abroad competition by tariff barriers or legal barriers; (ii) measures to open up markets that were formerly protected from new entrants as severe regulations regarding entry in the market were in place; (iii) iii) measures aiming to reduce the State' involvement in the economy and (iv) measures to enhance business initiatives (Nicodème and Sauner-Leroy, 2004). Liberalisation of potentially competitive sectors, extensive privatisations and deregulation of previously highly regulated sectors were the key objectives of the reforms implemented in most of the EU Member States.

More recently, several countries have made efforts to assess their legislation in order to identify and eliminate rules and provisions that may somehow distort the competitive and efficient functioning of the markets. These reforms contribute to ensure a competitive well-functioning market in order to provide consumers with products and services at low prices, wider choice and better quality. In the last years, several states were very actively involved in analysing their regulatory frameworks. For instance, the Greek Government together with the OECD made an assessment of existing regulatory constraints on competition in four essential sectors of the Greek economy: food processing, retail trade, building materials and tourism. In 
other words, an analysis on the national legislation was carried out in order to identify and eliminate competition-distorting rules and provisions. As a result of removing barriers, the OECD calculated a total effect for the Greek economy of approx. 5.2 billion euro, resulting from efficiency gains and lower prices on goods and services for consumers (OECD, 2014). Another example of a recent regulatory assessment is represented by Romania. In 2016, OECD carried out an assessment of legislation in three key sectors of Romania's economy: construction, freight transport and food processing. By removing unnecessary barriers and constraints, the project aimed to improve the businesses ability to operate in a competitive environment in the long run, with positive effects on productivity and economic growth - the estimated effect for the Romanian economy was of approx. 440 million euro (OECD, 2016).

However, despite recent reforms, markets do not always function well. Often companies, in their desire to gain market share and profit, resort to certain anticompetitive practices. Whenever competition rules are infringed, consumer welfare is harmed by permitting consumers to pay increased prices for lower quality products and reduced choice. In addition, governments have the capacity to restrict or distort competition in a market through state aid or through other forms of market intervention, such as regulatory constraints (for example, by regulations that, while aiming to achieve its policy objective, create unnecessary barriers to entry on a market or regulations that advantage some operators in the market in the detriment of others). Therefore, state authorities must use all their tools in order to ensure that competition works effectively in markets and that regulations, state interventions or undertakings do not hinder the process.

Nevertheless, competition should not be seen as a goal, but as a way to economic efficiency, higher productivity and economic growth. It is generally recognised that one of the key roles of competition policy is the attainment of economic growth, through the positive effect competition has on productivity. In this context, competition is an intermediate objective and productivity is the final goal. Defined as the measure of an economy's ability to produce goods and services (outputs) from a given set of resources (inputs), an increased productivity allows a greater output to be produced with the same inputs. Related to productivity, Paul Krugman once stated 'Productivity isn't everything, but in the long run it is almost everything'.

Most empirical papers that aimed to investigate the relationship between deregulation/liberalisation and productivity have confirmed the positive link between the two variables (Nicolletti and Scarpeta, 2003; Ospina and Schiffbauer, 2010). Generally, in the long run deregulation and liberalisation lead to higher levels of productivity and increase the overall economic growth because competitive pressures are likely to enhance productivity improvements, forcing firms to make their production and distribution more efficient and to make efforts to innovate.

412 Review of International Comparative Management Volume 19, Issue 4, October 2018 


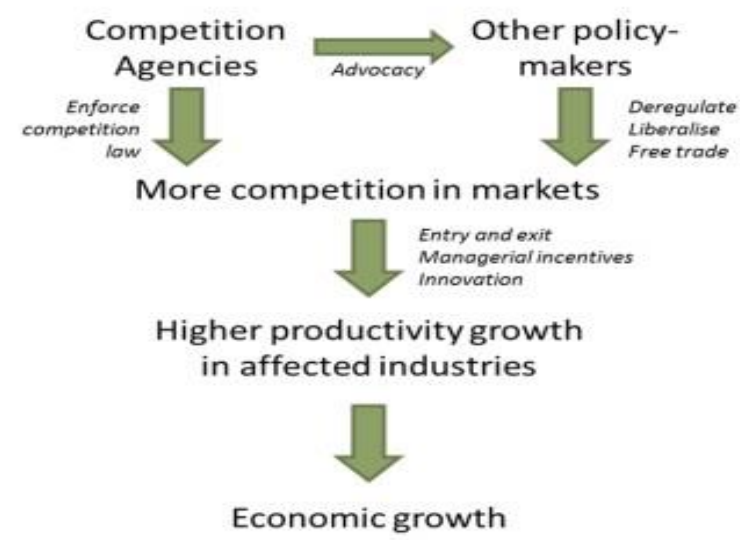

Figure 1. Competition and Growth, OECD (2013)

\section{Competition and Growth}

There is an extensive economic literature that supports the existence of a positive link between competition and productivity through two different types of analysis: (i) studies that analyse the relationship between competition and productivity across many product markets using firm-level micro data and (ii) studies which investigate the relationship between competition and productivity in a market overtime, following the changes in the level of competition resulting from deregulation or other changes in the market structure.

Based on an analysis of approx. 670 UK companies over the period 19721986, Nickell (1996) investigates how competition as measured by market share, market concentration, a survey-based measure of competition and the level of rent affects firm level productivity and confirms a positive impact of market competition on the level of productivity. More precisely, the author finds that market power, as captured by market share, generates reduced levels of productivity and also that lower levels of rents are associated with higher rates of total factor productivity growth.

Disney, Haskel and Heden (2000) extend this analysis and investigate the impact of restructuring on UK manufacturing productivity growth relying on a larger data set of around 143.000 UK manufacturing firms over the period 1980-1992 which permits the authors to identify entry, exit and survival. The main evidence of the study is that for the period 1980-1992 external restructuring meaning entry, exit and the reallocation of market shares accounts for roughly $50 \%$ of labour productivity growth and 80 to $90 \%$ of total factor productivity growth, concluding that competition significantly increases productivity growth.

As an alternative to using proxy variables for competition intensity such as market concentration, profit margin or number of entrants, several studies use the product market regulation indicator as an inverse measure of competition. In a cross- 
country study based on both economy-wide and industry-level regulatory indicators, Nicoletti and Scarpetta (2003) assess if the regulatory policy affects the multi-factor productivity, using data for 18 OECD countries over the period 1984-1998. The authors find evidence of a positive relationship between competition and productivity, showing that both privatisation and entry liberalisation lead to productivity gains while strict regulation hinders the adoption of new technologies or the entry of new high-tech firms.

Analysing the effects of policy reforms regarding the entry conditions in the United Kingdom, Aghion et al. (2004) reveal that foreign entry drives to faster productivity growth in domestic incumbents firms. They use micro-level data on British companies for the period between 1980 and 1993 and empirically find that the entry of new firms had a positive impact on aggregate productivity in the UK, arguing that entry drives incumbent firms to innovate in order to escape entry.

Another example of a positive impact of competition is found by Maher and Wise (2005) who analyse the effects of regulatory reforms in UK. Their findings indicate that the reforms and particularly vertical separation into the UK electricity and gas sectors contributed to a rapid growth over the 1990s. Following the new policies, market concentration in electricity generation and in gas were the lowest in the European Union and the annual productivity growth averaged approx. $10 \%$ a year in the analysed period. The resulting benefits were transferred to consumers in terms of lower prices and better quality in services. Furthermore, the authors analyse the liberalisation and reorganisation of the rail industry over the same period and find an increased efficiency, after decades of decline. They find that total passenger/kilometre grew by 22\% between 1992 and 2001 while total tonne/kilometre grew by $17 \%$ in the same period. However, a series of problems regarding service quality, safety and investments were identified, leaving room for improvement.

Similar results are found by Ospina and Schiffbauer (2010) who investigate the impact of competition on productivity using firm-level data from the World Bank Enterprise Survey database for a sample of 27 countries from Eastern Europe and Central Asia which implemented significant product-market reforms. They use several measures for firm productivity and competition and find evidence of a positive causal effect of competition on firm productivity. Moreover, as not all the analysed countries implemented entry deregulation reforms in the same period, a difference-in-difference estimation is performed in order to investigate the causality from the observed change in competition brought by entry reform on productivity growth. The results show that reformed countries experienced a more increased productivity related to the non-reformed countries and that contribution to productivity growth due to competition spurred by entry reforms is between $12 \%$ and $15 \%$.

Daveri et al. (2010) empirically investigate the effects of entry regulation implemented in France and Italy over the 1998-2007 period on the 
firms' mark-up and productivity. They use firm-level data on both countries to compute the productivity indicator and then, as a proxy for regulation, they use the OECD product market regulation indicator for retail, professional services, transport and communication. Their results show that entry barriers are associated with higher mark-ups and that higher mark-ups negatively impact firms' economic performance mostly in the long-run.

In a more recent cross-country study, Arnold, Nicoletti and Scarpetta (2011) use the OECD's Product Market Regulation index as a measure for regulation and empirically investigate how regulation affects the firm-level TFP growth across 10 European countries and several non-manufacturing sectors. They find that product market regulation tends to negatively impact firms' performance and, moreover, it seems the negative effects are stronger for the firms with an above-average productivity growth.

Looking at the impact of changes in competition resulting from deregulation, Boylaud and Nicoletti (2001) analyse the liberalisation of the road freight industry across OECD member countries and conclude that liberalisation has improved efficiency and consumer welfare in the countries that have implemented reforms. Particularly, liberalisation has increased business entry, has decreased price and has led to a better service quality.

Similarly, Bundeskartellamt analyse the effects of liberalisation on the market for the recovery and recycling of sales packaging discarded by private end consumers and found that, as the market opened up to competition, being operated by nine service providers instead of one, previous annual total costs of around two billion euros have fallen under one billion euros per year (Bundeskartellamt, 2012).In addition to reducing cost of packaging disposal, opening up the market also drove to a wave of innovation in technology for sorting the mix of waste material in the yellow bin, resulting in higher quality recycling.

Nevertheless, in the analysis of the Japanese industries based on industry-level data between 1980 and 2008, Ambashi (2013) finds a positive correlation between the level on competition measured by the Lerner index and the TFP growth in the manufacturing industries throughout the entire analysed period, while for the non-manufacturing industries the relationship is slightly negative for the period between 1995-2008, supporting the Schumpeterian hypothesis for the non-manufacturing industries. Moreover, the paper finds a weak inverted-U shape relationship between competition and innovation as showed by Aghion et al.(2005) in all industries.

The relationship between competition and innovation has been highly debated. On the one hand, there are some studies in line with the Schumpeterian theory suggesting that a higher competition can discourage innovative activity, as competition reduced the profits that can be obtained 
when a successful innovation is patented (Aghion and Howitt, 1992). According to Schumpeter (1942), new firms improve over and destroy existing firms in a process of a creative destruction. In this framework, in the Schumpeterian view, the prospect of monopoly rents stimulates firms in their innovative activity, whereas a strong competition may hamper innovation because it reduces rents and lowers the incentives to invest in R\&D.

More recent studies debated this idea in several ways. New endogenous growth models extend the basic Schumpeterian models suggesting that firms' decision to perform $R \& D$ and introduce innovations is based on the profits they will obtain post-innovation, in other words, they compare present profits without innovation with post-innovation profits (Aghion and Howitt 1998; Aghion et al. 2001). When their profits following innovation are reduced by strong competition, expenditures on $R \& D$ and innovations decrease. Then again, when the escape-competition effect is strong, firms will perform innovations in order to preserve their profits. Aghion et al. (2004) argue that in oligopolistic markets where firms have similar cost structures, being „neck-and-neck”, competition increases the incentives to engage in innovation activities in order to improve production processes and reduce costs and, finally, catch up with the market leader. Furthermore, the distance to the technological frontier seems to be an essential element in the relationship between competition and innovation. Higher threat of entry in sectors which are close to the technological frontier will encourage incumbents' innovative activities while it may deter innovation in sectors that are initially far below the technological frontier (Aghion et al. 2004; Acemoglu et al. 2006; Aghion et al. 2009.)

However, the link between competition and innovation may be a nonlinear one. Aghion et al. (2005) provide evidence of a non-linear relationship between product market competition and innovation in the form of an inverted-U shape, based on UK panel data for the period 1968-1997. They argue that the inverted-U shape results from the fact that both very high and very low degree of competition discourage firm from innovating. On the one hand, there is the Schumpeterian effect according to which too much competition provides lower incentives to firms to innovate because competition reduces firms' expected rents from innovating and, on the other hand, there is the escape-competition effect which enhance firms in neck-andneck sectors with reduced competition to introduce products with better quality and lower costs in order to move away from their competitors. Thus, the type of industry represents an essential element in the relationship between competition and innovation. It seems that moderately competitive environments are the ones which encourage most innovation, with both

416 Review of International Comparative Management Volume 19, Issue 4, October 2018 
monopoly and highly competitive markets giving rise to lower incentives to engage in innovative activity.

As we have seen, a large number of empirical papers confirmed a positive effect of competition on productivity growth. But how can competition bring higher productivity? Both theoretical and empirical studies suggest that there are three main channels through which competition can lead to productivity gains. First, competition allows for more productive firms to increase their market share to the detriment of the less productive ones through an allocative efficiency channel. In such cases, the less efficient firms may exit the market and be replaced by new entrants or growing firms. In this way, the level of competition increases and as a consequence mark-ups tend to decrease; also the overall efficiency in the market rises as the less productive firms exit the market and are replaced by more productive firms. Second, within a competitive environment, competition puts pressure on managers to work harder in order for firms to become more efficient and to provide better products and services at the lowest costs, raising productive efficiency. On the opposite, firms operating under monopoly are often associated with an inefficiency effect. As Leibenstein (1966) stated, „for a variety of reasons people and organisations normally work neither as hard or as effectively as they could. In situations where competitive pressure is light, many people will trade the disutility of greater effort, or search for the utility of feeling less pressure and of better interpersonal relations". Thus, lack of competition weakens the managers' incentive to improve performance since they are protected from competition and already earn extra profits. Competition can help to eliminate slack in the use of resources through the disciplining effect on managers. Third, competitive pressures force firms to innovate in order to differentiate themselves and move away from their competitors by providing consumers more attractive products and services. Consequently, firms continually develop new and better products and services in order to gain more market share. In other words, competition drives to technological progress through a dynamic efficiency channel. 


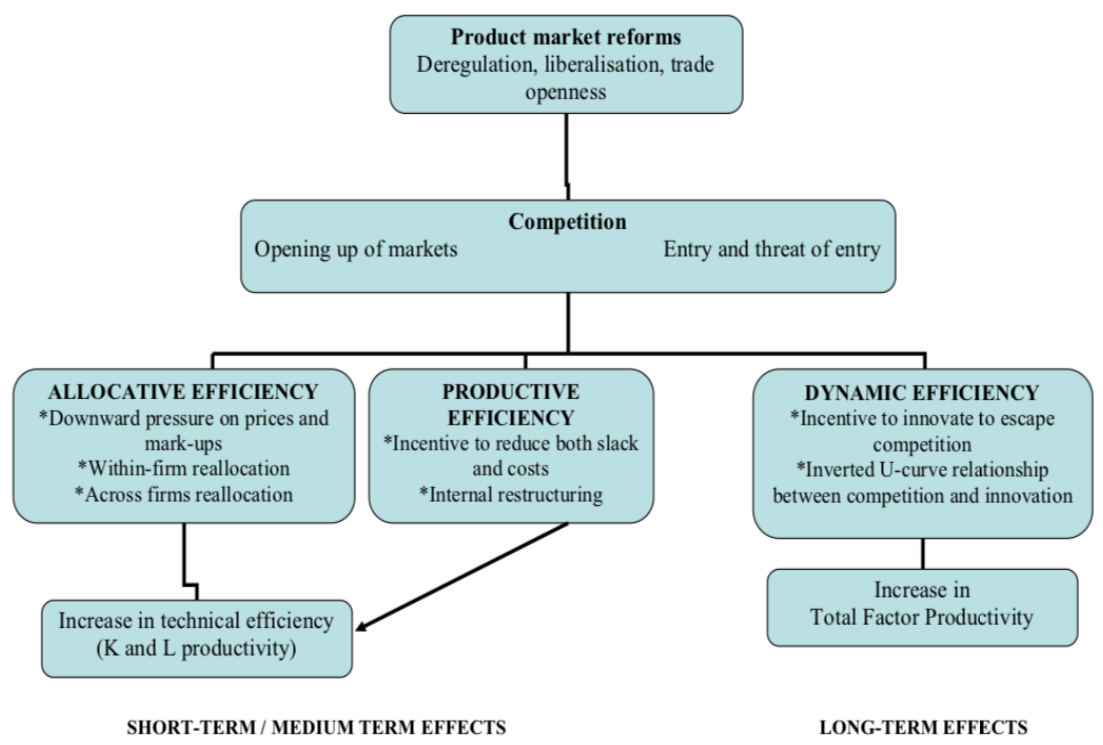

Figure 2. The Overall Impact of Pro-Competitive Product Market Reforms on Productivity, Nicodème and Sauner-Leroy (2004)

\section{Final Remarks}

In this paper we review theory and evidence on the link between competition and productivity, describing also the main mechanisms through which competition can be expected to affect firms' productivity and ultimately aggregate productivity growth.

Our main findings are highlighted as follows:

- A large body of empirical papers confirms a positive effect of competition on productivity growth, suggesting that competition has promoted efficiency and consumer welfare in the countries that have implemented reforms of deregulation and liberalisation. Moreover, there is evidence that stringent market regulatory frameworks negatively affect firms' productivity;

- A fierce competition forces firms to lower their inefficiencies like the managerial slack and in this way to enhance the (static) efficiency in the market. In addition, competition may stimulate firms to adopt better technologies or to develop new products and enhance the dynamic efficiency in the market.

- The link between competition and innovation is often found to be nonlinear. According to neo-Schumpeterian analyses, firms' decision to perform R\&D and introduce innovations is based on the profits they will obtain post-innovation. When their post-innovation profits are reduced by strong competition, expenditures on R\&D and innovations decrease. On the contrary, when competition is limited,

418 Review of International Comparative Management

Volume 19, Issue 4, October 2018 
firms intensify their innovative efforts in order to obtain a competitive advantage and move away from their competitors. The form of the inverted-U shape relationship between competition and innovation results from the fact that both very high and very low degree of competition discourage firm from innovating.

- However, it also appears that the impact of competition on innovation depends on certain characteristics of countries, industries and firms. The distance of the firms in a sector to the technological frontier influence the link between competition and innovation. In sectors that are closer to the technology frontier a greater competition has a positive impact on incumbents' productivity compared with sectors far behind the frontier, where competition may discourage firms to engage in innovation.

In light of the above analysis, competition should be regarded as a way to economic growth, having a great importance for firms' efficiency and productivity. By providing a proper regulatory framework and removing regulatory constraints, governments can promote competition and enhance economic growth. Moreover, competition authorities should be empowered with effective tools in order to detect and enforce anticompetitive practices or state interventions and, thus, ensure that competition works effectively in markets.

\section{References}

Acemoglu, D., Aghion, P. and Zilibotti, F., 2006. Distance to frontier, selection and economic growth. Journal of the European Economic Association, (4:1), pp. 37-74.

Aghion, P. and Howitt, P., 1992. A Model of Growth through Creative Destruction. Econometrica 60, no. 2: 323-351.

Aghion, P. and P. Howitt, 1998. Market structure and the growth process, Review of Economic Dynamics, 1(1): 276-305.

Aghion, P. and Howitt, P., 1998. Endogenous Growth Theory. MIT Press, Cambridge MA, USA.

Aghion, P., Harris, C., Howitt, P. and J. Vickers, 2001. Competition, imitation and growth with step-by-step innovation. Review of Economic Studies, vol. 68, pp. 467-492.

Aghion, P., Blundell R., Griffith R., Howitt P. and Prantl S., 2004. Entry and Productivity Growth: Evidence from Micro level Panel Data. Journal of the European Economic Association 2:2-3 (April-May 2004), 265-276.

Aghion, P., Bloom, N., Blundell, R., Griffith, R. and Howitt, P., 2005. Competition and innovation: An inverted U relationship. Quarterly Journal of Economics, Vol. 120, No. 2. 
Aghion, P., Blundell, R., Griffith, R., Howitt, P., and Prantl, S., 2009. The Effects of Entry on Incumbent Innovation and Productivity. Review of Economics and Statistics, 91, 1, 20-32.

Ahn, S., 2002. Competition, Innovation and Productivity Growth: A Review of Theory and Evidence. OECD Economics Department Working Papers, no. 317, OECD Publishing.

Ambashi, M., 2013. Does Competition Improve Industrial Productivity? An Analysis of the Japanese Industries on the Basis of Industry-Level Panel Data. Discussion papers 13098, Research Institute of Economy, Trade and Industry (RIETI).

Arnold, J., Nicoletti G. and Scarpetta, S., 2011. Regulation, Resource Reallocation and Productivity Growth, Nordic Economic Policy Review, Issue 2.

Bassanini, A. and Scarpetta, S., 2001. The driving forces of economic growth: panel data evidence for the OECD countries. OECD Economic Studies, No. 33.

Boylaud, O. and Nicoletti, G., 2001. Regulatory reform in road freight, OECD Economic Studies No. 32, 2001/I.

Bundeskartellamt, 2012. Sector Inquiry into Compliance Schemes - Interim results of the opening-up of the sector to competition, Bundeskartellamt 2012.

Daveri F., Lecat, R. and Parisi, M.L., 2010. Service deregulation, competition and the performance of French and Italian firms. Paper presented at the OECDBanque de France conference on "Structural reforms, crisis exit strategies and growth", 9-10 December.

Disney, R., Haskel, J. and Heden, Y., 2003. Restructuring and Productivity Growth in UK Manufacturing, Economic Journal, 113.

European Commission, 2004. The EU Economy: 2004 Review.

Leibeinstein, H., 1966. Allocative efficiency vs. X-Efficiency. American Economic Review. 56:392-415.

Maher, M. and M. Wise, 2005. Product Market Competition and Economic Performance in the United Kingdom. OECD Economics Department Working Papers, No. 433, OECD Publishing, Paris.

Nicodème, G. and Sauner-Leroy, J.B., 2004. Product Market Reforms and Productivity: A Review of the Theoretical and Empirical Transmissions Channel. Economic Papers no. 2018, European Commission DirectorateGeneral for Economic and Financial Affairs, Brussels.

Nicoletti, G. and Scarpetta, S., 2003.Regulation, Productivity and Growth. Economic Policy, Vol. 36, pp. 11-72.

Nickell, S.J., 1996. Competition and corporate performance. Journal of Political Economy, Vol. 104, No. 4, pp. 724-46.

OECD, 2013. Factsheet on Competition and Growth. OECD Working Party 2 on Competition and Regulation.

OECD, 2014.OECD Competition Assessment Reviews: Greece. OECD Publishing.

OECD, 2016.OECD Competition Assessment Reviews: Romania. OECD Publishing.

420 Review of International Comparative Management

Volume 19, Issue 4, October 2018 
Ospina, S. and Schiffbauer, M., 2010. Competition and Firm Productivity: Evidence from Firm-Level Data. International Monetary Fund Working Paper No. WP/10/67, March 2010.

Rao, S., Ahmad A., Horsman, W. and Kapstein-Russell, P., 2001. The importance of innovation for productivity. International Productivity Monitor, $n^{\circ} 2$, Spring 2001.

Schumpeter, J., 1942. Capitalism, Socialism and Democracy. New York: Harper and Row.

Stucke, M. E., 2013. Is Competition Always Good? Journal of antitrust Enforcement 1 (1), 162-197. 